\title{
OBITUARIES
}

For the full versions of articles in this section see bmj.com

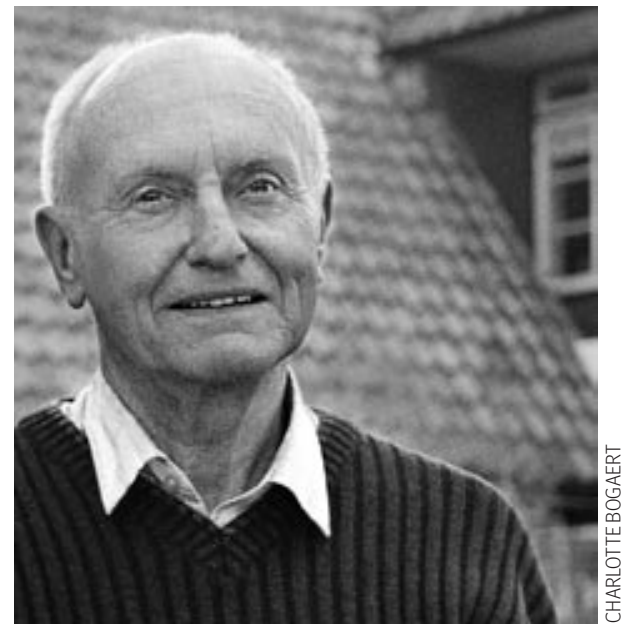

\section{Andries Postma}

\section{General practitioner involved in first case to change Dutch law on euthanasia}

In 1971 Andries Postma was an unknown Dutch general practitioner working in the quiet village of Noordwolde in rural Friesland. But his support for his wife, also a general practitioner, in what they were convinced was the mercy killing of her mother ensured their name a place in medical history.

Postma and his wife neither sought publicity nor set out to challenge Dutch law banning euthanasia. Still the Postma case was reported around the world and its shock waves continue to shape Dutch medical practice today.

As the first euthanasia test case, it broke social taboos in a country with strong Christian traditions. It also reflected a new wave of concern among many young medical professionals about the limits of medical care and patients' self determination.

Many in Dutch society, including the Postmas' fellow villagers in Noordwolde, shared their belief that they were morally in the right, even though his wife was technically guilty of murder.

Their actions were the spark that launched the Dutch Voluntary Euthanasia Society, and 20 years later resulted in a law protecting doctors carrying out euthanasia within legally defined boundaries.

Postma was born in 1926 in Hardegarijp, near Leeuwarden, in the northerly province of Friesland. He studied medicine in Groningen, where he met his wife, Truus, and together they set up a general practice in Noordwolde in the early 1950s.

Postma was a popular doctor and active in village affairs. It is believed he first expressed in public his strong views on the rights of everyone to a good and conscious death in 1965 in a local Friesian language magazine.

Six years later these theoretical views were cast in a sharp personal perspective as he and his wife faced up to the suffering of her severely handicapped mother. She had suffered a brain haemorrhage, was deaf, had difficulty speaking, and had to be tied to her chair in her nursing home to avoid her falling. She repeatedly begged her daughter to end her life. Eventually she agreed, injecting her mother with $200 \mathrm{mg}$ morphine. They informed the nursing home director, who alerted the health inspectorate. His wife was charged under the law forbidding voluntary euthanasia, which theoretically carried a 12 year prison term. However, though the Leeuwarden court in 1973 found her guilty, she was given only a symbolic punishment-a one week suspended prison sentence and 12 months' probation.

Postma was described as the "help and support" of his wife both throughout the events surrounding his mother in law's death and later in court. In June that year they jointly wrote in the Dutch Journal of Medicine in response to the countless articles that the case had provoked.

They explained that at first they absolutely did not want the publicity for the case generated both in the Netherlands and abroad. But now it was in the open they felt it "should be exposed so that everyone can reflect on our experiences."

Calling for a change in the law, they wrote: "From the many letters we have received it appears clear to us that very many dying people suffer inhumanely and without any prospects. There must be another way."

This was too much at the time for the Royal Dutch Medical Association, which distanced itself from the judgment, arguing that voluntary euthanasia should remain a crime. It took a further 11 years before it was to accept the need for a change in the law.

Many in Dutch society had fewer qualms. The Dutch Voluntary Euthanasia Society was launched in the same month as Postma's wife was convicted, holding its first meeting at Vinkenga, a small hamlet just a few miles from the Postmas' home.

Though Postma initially played no formal part, he was involved from the start in discussions about the new society. $\mathrm{He}$ thought the many reactions to the Postma case were reason to support it. He acted as a voluntary adviser on complex decisions surrounding terminal care. He eventually became its chairman for several years. In the 1980s he and his wife were made honorary members for their "contributions to the debate within society."

Last month the society described Postma as a "passionate fighter for the right of a free choice at the end of life." The society's director, Rob Jonquière, said that he was a man of mercy and integrity who believed that rights belonged to people, and doctors, unless they had strong objections of principle, should respect them. "He was one of those doctors who saw it as a privilege to be able to relieve patients of their suffering."

He believes neither of the Postmas had any intention of making a test case, but simply acted in a way "doctors have done for centuries" when confronted with desperate patients.

However, Postma did become a test case, which, together with three others, Schoonheid, Chabot, and Brongersma, has defined current policy. Because the court imposed such a lenient sentence, and for the first time accepted conditions under which euthanasia by doctors might be defendable-the patient is incurably ill, suffering unbearably, and has repeatedly requested euthanasia-it was seen as a signal that euthanasia could be possible.

Postma died aged 80. He leaves a wife, Truus, and five children.

\section{Tony Sheldon}

Andries Postma, general practitioner Noordwolde, Friesland, Netherlands (b 1926; q Groningen 1955), d 7 December 2006. 
Mary Ann Christina Adams

Former general practitioner London (b 1908; q London 1934),

d $\mathbf{1 7}$ September 2006.

The career of Mary Ann Christina Adams spanned the decades from the 1930s to the 1980s. After some years working with Joan Malleson she started her own practice in London. Her patients were mostly women, and when a baby was due she was unfailingly on call to be there at the birth. Mary loved books, paintings, theatre, and music. She was completely at home with children, and one of her great interests was education. For many years she was governor of Moreton Hall in Shropshire and helped steer the school through difficult times in the 1970s. Mary remained fit and active into old age, but an accident in 1992 left her much weakened, and she never fully recovered.

Henry Maas

\section{John Edward Buck}

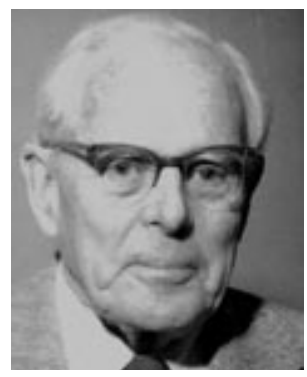

Former consultant orthopaedic surgeon Woolwich and Greenwich (b 1915; q Edinburgh 1938; FRCS), d 30 March 2006.

John Edward Buck joined the army in 1940, becoming medical officer to the 151 (British) Parachute Battalion in India. His battalion later took part in the capture of Taranto and then, as part of the 1st Airborne Division, fought at Arnhem, where John was captured and imprisoned until the end of the second world war. As consultant orthopaedic surgeon in Woolwich and Greenwich he acted as a civilian consultant to the military hospitals. He was one of the first to develop internal fixation of the spine in spondylosis. A keen sportsman until late in his life, he was medical adviser to Charlton Athletic Football Club. He leaves a wife, Dorothy.

Farid Khan, William Scott

\section{James Douglas ("Dougie") George}

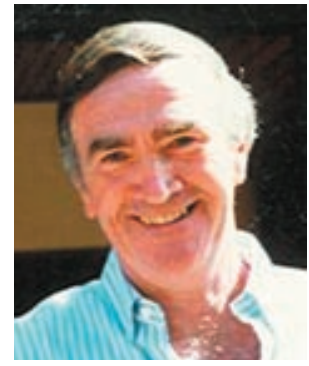

Former consultant general surgeon Norfolk and Norwich Hospital (b 1935, q Queen's University, Belfast, 1961; FRCS, MCh), died from lung cancer on 26 January 2006.

James Douglas George ("Dougie”) started his career in Belfast but completed his training at the Norfolk and Norwich Hospital. He became a consultant in 1970 , retiring in 2000. A "surgeons' surgeon," he was an exponent of aspiration biopsy as a diagnostic tool. He collected antique surgical instruments and lectured on medical diagnostics in paintings. Later he followed his interest in art and commerce by opening and running an art gallery in London with his wife until his death. He leaves a wife, Vera; two children; and four grandchildren.

Alan Green, David Thomas, Bruce George

\section{Neville Howard}

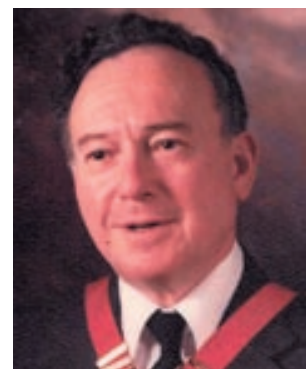

Former general practitioner Southport (b 1928; q Leeds 1952; DPH, DIH), d 26 August 2006.

After completing national service and training in dermatology, general medicine, and general practice, Neville Howard undertook diplomas in public health and industrial medicine. After a brief frustrating period as a medical officer he returned to general practice. He continued to work as a single handed general practitioner in Southport, where he was a passionate advocate for patients and a scourge of poor administration. He had great clinical wisdom and was a gifted teacher and communicator. Despite his workload he sustained his interest in dermatology. He leaves a wife, Marion; two children; and three grandchildren.

Robin Howard, Sarah Howard

\section{Nicholas James Taffinder} Consultant surgeon William Harvey

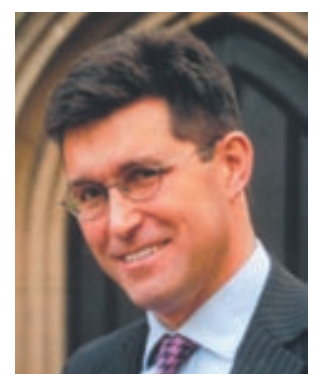

Hospital, Ashford, Kent (b 1965; q St Thomas's Hospital 1983; MS, FRCS), died from malignant fibrohistiocytoma on 25 November 2006.

After gaining his FRCS in 1993, Nicholas James Taffinder (“Nick”) became surgical registrar at St Mary's Hospital, London, where he completed his masters in laparoscopic surgery. $\mathrm{He}$ was appointed consultant surgeon to the William Harvey Hospital in 2001. He taught widely, was in the forefront of laparoscopic colorectal surgery, and researched into endoscopic surgery. He was a family man, an adventurer, a linguist, a sportsman, and a pilot. He was one of the hospital's most talented young consultants but in 2004 he was diagnosed with malignant fibrohistiocytoma. He underwent surgery, radiotherapy, and chemotherapy with exceptional courage. He leaves a wife, Jane, and four children.

Peter McDonald

\section{Jonathan Nicholas Wilson}

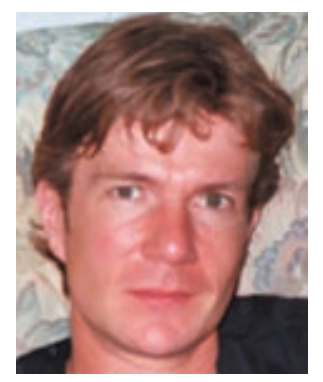

Specialist registrar in dermatology Amersham (b 1970; q Newcastle 1994; DPhil, MRCPCH), died in a swimming accident on 13 November 2006.

After qualifying, Jonathan Nicholas Wilson (“Jonny") continued postgraduate studies in paediatrics. He was awarded a DPhil in 2004 for his research at the Wellcome Trust Centre for Human Genetics, Oxford. After a year in the dermatology department at Great Ormond Street, London, he was appointed specialist registrar in dermatology at Oxford, intending ultimately to specialise in paediatric dermatology. Tragically, his career was cut short by a swimming accident on the Pacific coast of Costa Rica where he was doing voluntary conservation work. In his life and work, Jonny epitomised all that is best in the practice of paediatrics.

\section{Michael Wilson, David Wilson,} Andrew Wilson

\section{ADVICE}

We will be pleased to receive obituary notices of around 250 words. Pressure on space means that in most cases we will be able to publish only about 100 words in the printed journal, but we can run a fuller version on our website. We will take responsibility for shortening. We do not send proofs. Good quality, original photographs are welcome. Please give a contact telephone number and, where possible, supply the obituary on a disk or by email to obituaries@ bmj.com If sending a picture electronically, please attach as a jpeg or a tiff rather than as part of a Word document. We need to know the year of birth and exact date of death of the deceased, and we prefer obituaries to state the cause of death. 